\title{
STRATEGI MARKETING AIRLINES UNTUK MENINGKATKAN PENJUALAN TIKET PESAWAT LOW COST CARRIER (LCC)
}

\author{
Primadi Candra Susanto $^{1}$, Aswanti Setyawati ${ }^{2}$, Hartono $^{3}$ \\ 1,2 Institut Transportasi dan Logistik Trisakti, Jakarta, Indonesia, \\ ${ }^{3}$ Puslitbang Transportasi Jalan dan Perkeretaapian, Jakarta, Indonesia
}

e-mail: primstrisakti@gmail.com, wanti61@yahoo.com ,ambonharto@gmail.com

\begin{tabular}{l} 
ABSTRACT \\
Tujuan penelitian ini bagaimana strategi pemasaran yang diterapkan maskapai penerbangan \\
berkonsep Low Cost Carrier, Di Indonesia transportasi udara sangat digemari konsumen \\
terutama dengan kehadiran konsep Low Cost Carrier merupakan model penerbangan yang unik \\
dengan menerapkan strategi penurunan biaya operasional (operating cost) dan efisiensi cost di \\
semua lini, maskapai melakukan hal-hal diluar kebiasaan maskapai pada umumnya. Beberapa \\
karakteristik dari maskapai Low Cost Carrier (LCC) atau penerbangan berbiaya murah adalah \\
standarisasi pada kabin dan armada pesawat, menghilangkan tipe kelas bisnis dalam layanan, \\
mengurangi atau menghilangkan layanan dalam pesawat (atau dalam kata lain, layanan tetap \\
diberikan namun biaya diluar harga tiket), menyederhanakan proses ticketing melalui teknologi \\
IT dengan mnggunakan tiket elektronik, beroperasi pada penerbangan berjarak pendek (poin to \\
poin), menyederhanakan atau menghilangkan program mileage (member), menggunakan \\
bandara sekunder untuk meminimalisir biaya layanan bandara pada jam sibuk, memanfaatkan \\
penggunaan armada pesawat secara maksimal untuk meminimalisir biaya perawatan armada. \\
Pelayanan ini berakibat dalam hal penurunan cost, namun faktor safety tetap dijaga untuk \\
menjamin keselamatan penumpang sampai ke tujuan. Low Cost Carrier adalah redefinisi bisnis \\
penerbangan yang menyediakan harga tiket yang terjangkau serta layanan terbang yang \\
minimalis. Fenomena LCC sebagai salah satu strategi penerbangan di Indonesia menyadarkan \\
masyarakat bahwa sekarang ini semua orang bisa melakukan perjalanan menggunakan pesawat \\
udara dengan harga yang terjangkau dan tidak lagi seperti jaman dahulu dimana penggunaan \\
transportasi udara hanya monopoli orang-orang dari kalangan menengah keatas saja \\
Kata Kunci : Strategi Marketing; Meningkatkan Penjualan Tiket; Low Cost Carrier. \\
\hline
\end{tabular}




\section{PENDAHULUAN}

Industri kepariwisataan Indonesia menempati urutan pertama sebagai penghasil devisa negara dan dilanjutkan industri pertambangan sebagai penghasil devisa kedua. besarnya potensi pariwisata yang dimiliki Indonesia dapat dilihat dari aset yang ada, antara lain berupa keanekaragaman budaya, adat istiadat, kekayaan flora dan fauna, serta keindahan alam. Indonesia yang merupakan negara kepulauan terbesar di dunia dengan total 13.487 pulau membutuhkan moda transportasi yang beragam sehingga dapat menghubungkan dan memudahkan wisatawan yang ingin mengunjungi suatu daerah tujuan wisata. Transportasi udara adalah salah satu moda transportasi yang biasanya digunakan oleh wisatawan untuk jarak tempuh yang jauh dengan waktu yang lebih cepat. Pada masa sekarang maskapai low cost carrier sangat popular di Indonesia. Maskapai low cost carrier di Indonesia berlomba-lomba untuk merebut hati masyarakat. Mulai dari harga yang terjangkau, armada baru, serta pelayanan yang memuaskan, adanya maskapai low cost carrier sangat membantu perekonomian masyarakat menengah kebawah.

Bisnis jasa pada dasarnya merupakan suatu bisnis yang tidak berwujud, yang dapat memenuhi kebutuhan dan keinginan konsumen. Salah satu bisnis jasa adalah bisnis penerbangan. Maskapai penerbangan adalah sebuah organisasi yang menyediakan jasa penerbangan bagi penumpang atau barang. Perusahaan maskapai tersebut menyewa atau memiliki pesawat terbang untuk menyediakan jasa transportasi. Dalam pelayanan jasa penerbangan terdapat 2 (dua) istilah penerbangan yaitu Penerbangan Full Service dan Penerbangan Low Cost, Istilah Penerbangan Full Service adalah maskapai yang memberikan layanan penuh, seperti layanan catering, koran/majalah dan flight entertain, sedangkan istilah Penerbangan "low cost" atau sering disebut Low Cost Carrier (LCC) atau Budget Airlines atau no frills flight atau juga Discounter Carrier merupakan model penerbangan yang unik dengan strategi penurunan operating cost. Low Cost Carrier melakukan eleminasi layanan maskapai tradisional yaitu dengan pengurangan catering, minimize reservasi dengan bantuan teknologi IT sehingga layanan nampak sederhana dan bisa cepat, namun faktor keselamatan tetap dijaga untuk menjamin keselamatan penumpang sampai ke tujuan. LCC adalah redifinisi bisnis penerbangan yang menyediakan harga tiket yang terjangkau serta layanan terbang yang minimalis. Intinya produk yang ditawarkan senantiasa berprinsip low cost untuk menekan dan mereduksi operasional cost 
sehingga bisa menjaring segmen pasar bawah yang lebih luas.

Sejalan dengan pertumbuhan ekonomi nasional, pertumbuhan kelas menengah, kondisi geografis, program pengembangan wisata Pemeritah dan prakiraan ekspansi yang dilakukan ke dalam market, industri penerbangan domestik diperkirakan akan bertumbuh ratarata $7,6 \%$ per tahun dalam periode 2015-2020.

\section{LANDASAN TEORI}

Menurut Tjiptono, Chandra, dan Adriana (2008:283), strategi pemasaran merupakan rencana yang menjabarkan ekspektasi perusahaan akan dampak dari berbagai aktifitas atau program pemasaran terhadap permintaan produk atau lini produknya di pasar sasaran tertentu. Strategi pemasaran mengandung keputusan dasar tentang pengeluaran pemasaran, bauran pemasaran, dan alokasi pemasaran.

Pentingnya kulaitas pelayanan dan produktifitas dalam pemasaran menurut Christopher lovelock, dkk (2013:152-153) Fokus pemasaran terhadap kualitas pelayanan adalah jelas; rendahnya kualitas akan menempatkan perusahaan pada kerugian kompetitif, berpotensi mengusir pelanggan yang tidak puas. Meningkatkan Produktifitas menjadi penting bagi pemasar karena beberapa alasan, Pertama, produktivitas membantu menurunkan biaya. Biaya yang lebih rendah berarti laba yang lebih tinggi, atau kemampuan untuk menekan harga. Perusahaan dengan biaya rendah di suatu industri memiliki pilihan untuk memposisikan diri sebagai pemimpin harga terendahbiayasanya menjadi kelebihan yang signifikan antara segmen pasar yang sensitif terhadap harga. Kedua, perusahaan dengan biaya lebih rendah juga menghasilkan margin yang lebih tinggi, memberi pilihan untuk mengeluarkan lebih banyak biaya daripada pesaing dalam kegiatan pemasaran, dan meningkatkan pelayanan pelanggan dan pelayanan tambahan. Perusahaan tersebut juga mungkin dapat menawarkan margin yang lebih tinggi dan memberikan keuntungan lebih untuk menarik distributor dan perantara terbaik. Ketiga adalah kesempatan untuk mengamankan masa depan perusahaan dalam jangka panjang melalui investasi pada teknologi pelayanan baru dan pada pennelitian untuk menciptakan pelayanan baru yang unggul. Perbaikan fitur, dan sistem pelayanan yang inovatif. Yang terakhir upaya untuk meningkatkan produktivitas sering mempengaruhi pelanggan, pemasaran yang bertanggungjawab untuk memastikan bahwa dampak negatif dapat dihindari atau diminimisasi dan prosedur baru secara hati-hati disajikan kepada pelanggan. Dampak positif dapat dijadikan sebagai keunggulan baru. 
Terdapat beberapa macam pengertian strategi dari para ahli. Menurut Marrus dalam Umar (2001:31) strategi didefinisikan sebagai suatu proses penentuan rencana para pemimpin puncak yang berfokus pada tujuan jangka panjang organisasi, disertai penyusunan suatu cara atau upaya bagaimana agar tujuan tersebut dapat dicapai. Strategi didefinisikan secara khusus sebagai tindakan yang bersifat incremental (senantiasa meningkat) dan terusmenerus, serta dilakukan berdasarkan sudut pandang tentang apa yang diharapkan oleh para pelanggan di masa depan (Prahalad dalam Umar, 2001:31).

Menurut Chandra (2002:93), strategi pemasaran merupakan rencana yang menjabarkan ekspektasi perusahaan akan dampak dari berbagai aktivitas atau program pemasaran terhadap permintaan produk atau lini produknya di pasar sasaran tertentu. Program pemasaran meliputi tindakan-tindakan pemasaran yang dapat mempengaruhi permintaan terhadap produk, diantaranya dalam hal mengubah harga, memodifikasi kampanye iklan, merancang promosi khusus, menentukan pilihan saluran distribusi, dan sebagainya.

Merumuskan strategi pemasaran berarti melaksanakan prosedur tiga langkah secara sistematis, bermula dari strategi segmentasi pasar, strategi penentuan pasar sasaran, dan strategi penentuan posisi pasar. Ketiga strategi tersebut adalah kunci di dalam manajemen pemasaran: a) Strategi Segmentasi Pasar Segmentasi pasar adalah proses membagi pasar ke dalam kelompok pembeli yang berbeda-beda berdasarkan kebutuhan, karakteristik, ataupun, perilaku yang membutuhkan bauran produk dan bauran pemasaran tersendiri. Atau dengan kata lain segmentasi pasar merupakan dasar untuk mengetahui bahwa setiap pasar terdiri atas beberapa segmen yang berbeda-beda. Segmentasi pasar adalah proses menempatkan konsumen dalam sub kelompok di pasar produk, sehingga para pembeli memiliki tanggapan yang hampir sama dengan strategi pemasaran dalam penentuan posisi perusahaan. (Setiadi. 2003:55)

Manajemen pemasaran dikelompokkan dalam empat aspek yang sering dikenal dengan marketing mix atau bauran pemasaran. Menurut Kotler dan Armstrong (2004:78) bauran pemasaran (marketing mix) adalah kumpulan alat pemasaran taktis terkendali yang dipadukan perusahaan untuk menghasilkan respon yang diinginkannya di pasar sasaran. Bauran pemasaran terdiri dari empat kelompok variabel yang disebut "empat P", yaitu: 1 . Product/Produk Produk berarti kombinasi barang dan jasa yang ditawarkan perusahaan kepada pasar sasaran. Elemen-elemen yang termasuk dalam bauran produk antara lain ragam produk, kualitas, design, fitur, nama merek, kemasan, serta layanan. 2. Price/Harga 
Harga adalah jumlah uang yang harus dibayarkan pelanggan untuk memperoleh produk. Harga adalah satu-satunya unsur bauran pemasaran yang menghasilkan pendapatan, sedangkan unsur-unsur lainnya menghasilkan biaya. Harga adalah unsur bauran pemasaran yang paling mudah disesuaikan dan membutuhkan waktu yang relatif singkat, sedangkan ciri-ciri produk, saluran distribusi, bahkan promosi membutuhkan lebih banyak waktu. 3. Place/Tempat Tempat atau saluran pemasaran meliputi kegiatan perusahaan yang membuat produk tersedia bagi pelanggan sasaran. Saluran distribusi adalah rangkaian organisasi yang saling tergantung yang terlibat dalam proses untuk menjadikan suatu produk atau jasa siap untuk digunakan atau dikonsumsi. Saluran distribusi dapat didefinisikan sebagai himpunan perusahaan dan perorangan yang mengambil alih hak atau membantu dalam pengalihan hak atas barang atau jasa tertentu selama barang atau jasa tersebut berpindah dari produsen ke konsumen (Kotler, 2005). 4. Promotion/Promosi Promosi berarti aktivitas yang menyampaikan produk dan membujuk pelanggan untuk membelinya.

Konsep ini diperkenalkan oleh Sven Groß dan Alexander Schröder (2007) dalam bukunya "Handbook of Low Cost Airlines". Sebuah maskapai penerbangan termasuk ke dalam maskapai penerbangan berbiaya murah apabila memenuhi kriteria-kriteria sebagai berikut: 1. Hanya memberikan satu kelas layanan penerbangan untuk penumpang, yaitu kelas ekonomi 2. Hanya memiliki satu tipe pesawat yang digunakan untuk mengurangi biaya pelatihan dan biaya pengoperasian 3. Standar pemeliharaan pada pesawat adalah standar

minimal

4. Tidak memberikan sistem pemesanan tempat duduk dan memungkinkan pemesanan lebih awal yang boleh memilih tempat duduk 5. Biaya penerbangan yang rendah dikarenakan biaya landasan di Bandara yang murah 6. Memiliki frekuensi penerbangan yang tinggi untuk memaksimalkan utilisasi pesawat dalam satu harinya 7. Rute yang sederhana (biasanya point to point) dikarenakan tidak terlalu banyak Bandara yang digunakan untuk

transit

8. Menekankan penjualan dengan menggunakan tiket secara langsung (tidak dijual melalui travel agent) dan lebih mengutamakan melalui call center dan internet untuk menekan biaya tiket 9. Lebih mengutamakan pada sistem tiket elektronik dan tidak menggunakan tiket konvensional 10. Awak pesawat bekerja ganda dan tanpa memberlakukan penanganan melalui ground handling sehingga dapat menghemat biaya tenaga kerja 11. Tidak menyediakan fasilitas makanan minuman atau snack dalam setiap 
penerbangan 12. Menerapkan pola tarif yang sangat sederhana pada satu tarif atau tarif sub kelas dengan harga mulai dari tarif promo/diskon.

\section{METODE PENELITIAN}

Metode penelitian ini merupakan studi literatur dengan membandingkan beberapa teori yang ada, penelitian sebelumnya dan wawancara dengan beberapa narasumber. Untuk memperoleh informasi dan data yang diperlukan dalam penulisan ini maka digunakan tehnik pengumpulan data sebagai berikut dokumen/kepustakaan, yaitu teknik memperoleh data dengan mempelajari dokumen-dokumen yang berhubungan dengan permasalahan yang diteliti. Teknik analisis data dalam penelitian ini menggunakan metode analisis secara kualitatif dengan pola berfikir induktif. Proses analisis tersebut dilakukan dengan teknik analisis data yang bersifat content analisis yaitu melalui tahap pendiskripsian secara rinci, sifat, ciri dan substansi data serta konteksnya, kemudian secara teoritik interpretatif dan menggunakan logika induksi kemudian ditarik suatu kesimpulan.

\section{PEMBAHASAN}

Untuk memenangkan persaingan dan menguasai pangsa pasar yang terbatas ini di butuhkan suatu strategi, salah satunya adalah strategi pemasaran yaitu salah satu cara memenangkan keunggulan bersaing yang berkesinambungan baik itu untuk perusahaan yang memproduksi barang atau jasa. Strategi pemasaran dapat dipandang sebagai salah satu dasar yang dipakai dalam menyusun perencanaan perusahaan secara menyeluruh. Dipandang dari luasnya permasalahan yang ada dalam perusahaan, maka diperlukan adanya perencanaan yang menyeluruh untuk dijadikan pedoman bagi segmen perusahaan dalam menjalankan kegiatannya. Alasan lain yang menunjukkan pentingnya strategi pemasaran adalah semakin kerasnya persaingan yang dihadapi oleh perusahaan pada umumnya. Dalam situasi yang demikian, tidak ada lagi pilihan lain bagi perusahaan kecuali berusaha untuk menghadapinya atau sama sekali keluar dari arena persaingan. Perusahaan harus meningkatkan efektifitas dan nilai pelanggan, bahwa respon yang paling baik untuk melindungi pasar yaitu dengan melakukan inovasi terus menerus (continous innovation). Perusahaan terus berusaha meningkatkan efektifitas kompetitif dan nilai perusahaan di mata konsumennya. Pemasaran perlu mendapat perhatian serius oleh Perusahaan Penerbangan. Terutama didalam proses penetapan strategi pemasaran harus benar-benar matang, sehingga strategi 
pemasaran yang dipilih akan mampu menembus pasar. Apalagi kondisi persaingan yang semakin ketat seperti saat ini, kemampuan untuk merebut pangsa pasar akan mempengaruhi kelangsungan hidup maskapai itu sendiri. Keadaan ini tidak terkecuali akan dihadapi oleh airlines. Suatu manajerial yang terdapat di dalamnya sangat membutuhkan perumusan strategi pemasaran yang tepat sebagai prioritas utama untuk menghadapi persaingan sebagai upaya mengembangkan pasar.

Perkembangan pada sektor industri penerbangan mendorong peningkatan persaingan antar maskapai penerbangan, terlebih lagi dengan adanya pemain baru dalam industri penerbangan yang melakukan positioning sebagai Low Cost Carrier. Low Cost Carrier (LCC) merupakan maskapai yang menawarkan tarif rendah, lebih rendah dibandingkan maskapai Full Service Carrier yang selalu memberikan pelayan secara prima dan memuaskan para pelanggannya saat menggunakan jasa perusahaan tersebut. Perusahaan penerbangan LCC melakukan penekanan dan pereduksian biaya operasional sehingga dapat menjaring segmen pasar bawah yang lebih luas, pelayanan yang memuaskan merupakan tujuan utama dari pihak perusahan penerbangan. Perusahan penerbangan dimaksudkan dapat memikat calon konsumen dan mempercayakan perjalanannya menggunakan transportasi udara yang diselenggarakan oleh perusahaan tersebut karena acuan untuk setiap perusahaan penerbangan yang harus diberi perhatian khusus adalah aspek yang berhubungan langsung terhadap konsumen yaitu aspek keselamatan, keamanan, tepat waktu, pelayanan, dan efisiensi. Kelima aspek tersebut harus serta merta dikondisikan kepada seluruh karyawan dan tingkat manajemen, sebab pencapaian keberhasilan industri penerbangan merupakan rangkaian yang saling berkaitan. Oleh karena itu, baik perusahaan full service ataupun LCC saling berkompetisi dalam memberikan kepuasan pelayanan kepada calon konsumen dengan kemudahan reservasi, mengadakan tiket promo dan ketepatan waktu saat melakukan perjalanan sehingga diharapkan dapat meningkatkan tingkat kepadatan penumpang (seat load factor).

\section{KESIMPULAN}

Maskapai penerbangan berbiaya murah (low cost carrier) merupakan sebuah maskapai penerbangan (airline) yang memberikan tarif rendah dengan cara menghapus beberapa layanan yang diterima penumpang pada umumnya dalam maskapai penerbangan lain. Saat ini industri yang bergerak di bidang 
jasa transportasi udara mengalami pertumbuhan yang sangat pesat. Hal ini dibuktikan dengan banyaknya perusahaan penerbangan asing maupun lokal yang bermunculan di Indonesia. Pertumbuhan industri tersebut tidak lepas dari adanya peningkatan daya beli konsumen terhadap jasa transportasi udara. Persaingan bisnis yang semakin ketat sekarang ini menyebabkan banyak perusahaan yang terlibat dalam pemenuhan kebutuhan dan keinginan konsumen. Hal ini seakan menuntut setiap perusahaan penerbangan harus menempatkan orientasi pada kepuasan pelanggan sebagai tujuan utama.

Perusahaan menyediakan layanan yang lebih baik dan pelanggan memiliki pengetahuan dan keterampilan untuk dapat memaksimalkan teknologi yang ada. Pada saat itu, baik dari pelanggan dan perusahaan akan sama-sama menciptakan nilai. Apabila nilai yang dirasakan oleh pelanggan adalah merupakan kepuasan dari layanan tersebut, maka pelanggan akan mengulangi untuk menggunakan layanan yang sama. Ini akan terjadi berkali-kali. Tetapi sebaliknya jika pada satu waktu pelanggan kecewa, ada kemungkinan mereka akan mencoba untuk melihat kemungkinan layanan dari kompetitor/pesaing untuk memenuhi kepuasan mereka. Jika ini terjadi maka pelanggan dapat beralih ke pesaing.

Dalam rangka menghadapi kekuatan persaingan perlunya strategi yang dikenal dengan nama strategi generik yang merupakan cara mendasar bagi perusahaan untuk mencapai profitabilitas di atas rata-rata industri dengan memiliki sustainable competitive advantage. Berikut ini jenis strategi generik Porter: a. Strategi keunggulan biaya menyeluruh Strategi keunggulan biaya menyeluruh adalah strategi yang digunakan untuk mencapai keunggulan biaya menyeluruh dalam industri melalui seperangkat kebijakan fungsional yang ditunjukkan pada sasaran utama. Keunggulan biaya memerlukan kontruksi agresif dan fasilitas skala yang efisien, usaha yang terus mernerus dalam mencapai penurunan biaya karena pengalaman, pengendalian dan overhead (biaya lain-lain) yang ketat, penghindaran pelanggan marginal, serta meminimalkan biaya dalam bidang-bidang seperti pelayanan, armada penjualan, periklanan dan lain-lain. b. Strategi diferensiasi, yaitu menciptakan sesuatu yang baru yang dirasakan oleh industri secara menyeluruh sebagai hal yang unik. Perusahaan akan menggunakan strategi diferensiasi bila ingin bersaing dengan pesaingnya dalam hal keunikan produk dan jasa yang ditawarkan. Keunikan tersebut dapat dilihat dari ciri produk yang menawarkan nilai-nilai yang dicari 
konsumen sehingga menjadikan produk tersebut unik dan berbeda dimata konsumen. Dalam strategi diferensiasi semua strategi dan kebijakan perusahaan harus dibuat berbeda dari pada pesaingnya. Perusahaan yang mengadopsi strategi ini biasanya memiliki banyak lini produk. Membuat produk dengan banyak model, fitur, harga dan lain-lain yang beragam. c. Strategi fokus, Strategi ini didasarkan pada pemikiran bahwa perusahaan dengan demikian akan mampu melayani target strategisnya yang sempit secara lebih efektif dan efisien dibandingkan pesaing yang bersaing lebih luas. Perusahaan yang memilih strategi fokus secara potensial juga dapat menghasilkan laba diatas rata-rata atas industrinya. Strategi fokus dapat berarti bahwa perusahaan mempunyai posisi biaya rendah dengan target strategisnya, diferensiasi atau keduanya.

\section{DAFTAR PUSTAKA}

Chandra, Gregorius. (2002). Strategi dan Program Pemasaran. Yogyakarta: Andi Ofset.

Grob \& Alexander Schroder, (2007). Handbook of Low Cost Airlines. Diakses melalui book.google.co.id pada tanggal 6 Agustus 2020.

Lovelock, C. Jochen,W \& Jacky M (2013). Pemasaran Jasa: Manusia, Teknologi,
Strategi: Perspektif Indonesia Jilid 2. Jakarta: Erlangga. (2005).

Setiadi, Nugroho J. (2003). Perilaku Kosumen: Konsep dan Implikasi untuk Strategi dan Penelitian Pemasaran. Jakarta: Kencana.

Umar, H. (2001). Strategic Management in Action, Konsep, Teori dan Teknik Menganalisis Manajemen Strategis Bisnis Unit Berdasarkan Konsep Michael R. Porter, Fred R. David dan Wheelan-Hunger. Jakarta: PT. Gramedia Pustaka Utama 